GRASAS Y ACEITES 67 (3)

July-September 2016, e146

ISSN-L: 0017-3495

doi: http://dx.doi.org/10.3989/gya.0439161

\title{
Culture of microalgae biomass for valorization of table olive processing water
}

\author{
C.G. Contreras ${ }^{\mathrm{a}, \mathrm{b}}$, A. Serrano ${ }^{\mathrm{a}}$, G. Ruiz-Filippi ${ }^{\mathrm{b}}$, R. Borja ${ }^{\mathrm{a}}$ and F.G. Fermoso ${ }^{\mathrm{a}, \bigotimes}$ \\ ${ }^{a}$ Instituto de la Grasa (C.S.I.C.), Edificio 46, Campus Universitario Pablo de Olavide, Ctra. de Utrera, Km. 1, 41013, Sevilla, Spain. \\ ${ }^{\mathrm{b}}$ School of Biochemical Engineering, Pontificia Universidad Católica de Valparaíso, Av. Brasil 2085, Valparaiso, Chile. \\ ${ }^{\square}$ Corresponding author: fgfermoso@ig.csic.es
}

Submitted: 05 April 2016; Accepted: 05 May 2016

SUMMARY: Table olive processing water (TOPW) contains many complex substances, such as phenols, which could be valorized as a substrate for microalgae biomass culture. The aim of this study was to assess the capability of Nannochloropsis gaditana to grow in TOPW at different concentrations (10-80\%) in order to valorize this processing water. Within this range, the highest increment of biomass was determined at percentage of $40 \%$ of TOPW, reaching an increment of $0.36 \pm 0.05 \mathrm{mg}$ volatile suspended solids (VSS)/L. Components of algal biomass were similar for the experiments at $10-40 \%$ of TOPW, where proteins were the major compounds (56-74\%). Total phenols were retained in the microalgae biomass $(0.020 \pm 0.002 \mathrm{~g}$ of total phenols $/ \mathrm{g}$ VSS). Experiments for $80 \%$ of TOPW resulted in a low production of microalgae biomass. High organic matter, nitrogen, phosphorus and phenol removal were achieved in all TOPW concentrations. Although high-value products, such as proteins, were obtained and high removal efficiencies of nutrients were determined, microalgae biomass culture should be enhanced to become a suitable integral processing water treatment.

KEYWORDS: Microalgae biomass; Phenols; Proteins; Table olive processing water; Valorization

RESUMEN: Cultivo de biomasa de microalgas para la valorización del agua de elaboración de las aceitunas de mesa. El agua resultante del proceso de elaboración de la aceituna de mesa (TOPW) presenta un elevado contenido en sustancias complejas, como fenoles, que podría permitir su uso como sustrato para el cultivo de microalgas. El objetivo de este estudio se centra en evaluar la capacidad de crecimiento de Nannochloropsis gaditana en TOPW a distintas concentraciones (10-80\%) con vistas a la valorización de estas aguas. El mayor incremento de biomasa se obtuvo para un porcentaje del $40 \%$ de TOPW, alcanzando un aumento de $0.36 \pm 0.50$ mg sólidos en suspensión volátiles (SSV)/L. Los componentes presentes en la biomasa han sido similares para los experimentos con 10-40\% de TOPW, siendo las proteínas los compuestos mayoritarios en todos los casos (56-74\%). Los fenoles totales quedaron retenidos en las microalgas, alcanzando una concentración media de $0.020 \pm 0.002 \mathrm{~g}$ fenoles totales/g SSV. En los experimentos con $80 \%$ de TOPW se obtuvieron producciones bajas de microalgas. Las eficiencias de eliminación de materia orgánica, nitrógeno, fósforo y fenoles fueron elevadas para las diferentes concentraciones estudiadas de TOPW. Aunque se ha obtenido una elevada producción de compuestos de interés y altas eficiencias de eliminación de nutrientes, el cultivo de microalgas debería mejorarse para llegar a ser un sistema integral válido para el tratamiento de TOPW.

PALABRAS CLAVE: Agua resultante del proceso de elaboración de aceituna de mesa; Biomasa microalgal; Fenoles; Proteínas; Valorización

Citation/Cómo citar este artículo: Contreras CG, Serrano A, Ruiz-Filippi G, Borja R, Fermoso FG. 2016. Culture of microalgae biomass for valorization of table olive processing water. Grasas Aceites 67 (3): e146. doi: http://dx.doi. org/10.3989/gya.0439161.

Copyright: (C) 2016 CSIC. This is an open-access article distributed under the terms of the Creative Commons Attribution-Non Commercial (by-nc) Spain 3.0 Licence. 


\section{INTRODUCTION}

Table olives are one of the most traditional fermented vegetable of Mediterranean countries. The world production of table olives has been increasing in recent years. This production is estimated to reach 2,742,500 tons for the 2015/16 season, with 520,000 tons produced in Spain (IOOC, 2016). Green Spanish style is the most prominent industrial preparation of table olives which reaches $60 \%$ of the total Spanish production (Sánchez et al., 2006). Table olive preparation consists of treating the fruits with a dilute $\mathrm{NaOH}$ solution to hydrolyze their natural bitterness (oleuropein), followed by one or two water washings to remove the alkali excess and, finally, a spontaneous lactic acid fermentation in brine.

Table olive processing water (TOPW) contains many complex substances and a high organic content, which represent a serious environmental problem in Mediterranean countries (Brenes et al., 1989; Parinos et al., 2007). The main organic constituents of TOPW are sugars and phenolic compounds, basically, tyrosol, hydroxytyrosol, ferulic acid and caffeic acid; some nitrogenous compounds, organic acids, tannins, pectin and oil residue compounds (Sánchez et al., 2006). The inorganic fraction consists of both high concentrations of sodium chloride and sodium hydroxide, which are used for olive de-bittering and fermentation, as well as trace amounts of various metals. TOPW phytotoxicity is due to the phenolic substances, which confer a sharp characteristic odor and make TOPW toxic and resistant to biodegradation (Ayed et al., 2015).

Some species of microalgae show a remarkable degree of adaptation to a variety of phenols and high salt concentrations (Kaçka and Dönmez, 2008). These microalgae could grow in e.g. wastewaters derived from brine of table olives, reducing the need for fresh water and underlining the necessity for very low-cost culture systems.

Assimilating nutrients and polluting compounds from wastewaters through photosynthesis produce dissolved oxygen that might be used by bacteria to further oxidize organic wastes (Montingelli et al., 2015). The subsequent harvest of the algal biomass permits the recovering of nutrients and valuable compounds from the wastewater, which can be used as substrates for different valorization processes such as biofuel production or high-value compound production. Wang et al. (2010) demonstrated this concept by testing the cultivation of green algae Chlorella sp. in municipal wastewaters from different process treatment stages. The results showed that growing algae in concentrated wastewater, which is the wastewater generated in the sludge centrifuge, has a potential in terms of both nutrient removal and biomass cultivation for biofuel production.
Microalgae have been proposed as protein sources and procedures for protein isolation have been developed for protein-producing microalgae (Gerde et al., 2013). In addition, microalgae are important sources of bioactive natural substances, such as long-chain polyunsaturated fatty acids, carotenoids and tocopherols, which can be utilized in the food industry for the development of functional foods, which provide health benefits. Nannochloropsis gaditana is a microalga belonging to the class Eustigmatophycea and is characterized by its high capacity to accumulate proteins and lipids, between $65 \%$ and $70 \%$ (dry basis) (Gerde et al., 2013; Millao and Uquiche, 2016) and carotenoid pigments, including astaxanthin, $\beta$-carotene, canthaxanthin, neoxanthin, violaxanthin and zeaxanthin. Carotenoids are particularly used as functional additives given their antioxidant activity, nutritional activity as provitamin A and as food colorants. Tocopherols are antioxidants that have a protective effect against the oxidation of unsaturated lipids. These natural compounds may be used in nutraceutical applications and in the development of functional products. In addition, $N$. gaditana has shown high biomass productivity compared to other screened microalgae such as Scenedesmus quadricauda or Chlamydomonas reinhardtii, under autotrophic conditions (Sforza et al., 2010).

The aim of this study was to assess the capability of $N$. gaditana to grow in TOPW at different concentrations. The contents of total phenols, proteins, lipids and total carbohydrates were determined in the microalgal biomass after the growth period with a view to its recovery and valorization. The degradation of organic matter was also evaluated in each case studied on the basis of total organic carbon removal efficiency. Finally, the biomass specific growth rate was obtained by using a first-order kinetic model.

\section{MATERIAL AND METHODS}

\subsection{Microalgae, synthetic medium and table olive processing water used}

A $N$. gaditana strain was obtained from the University of Huelva (Spain). A stock culture of $N$. gaditana was maintained photoautotrophically in an 8.0-L glass bottle, containing 5.0-L of culture, by addition of a synthetic medium. Growth conditions were maintained at an aeration rate of $0.5 \mathrm{~L} /(\mathrm{L} \cdot \mathrm{min})$ under solar light of $4.6 \mu \mathrm{mol}$ photons $/\left(\mathrm{m}^{2} \cdot \mathrm{s}\right)$ and at a temperature of $25 \pm 2{ }^{\circ} \mathrm{C}$.

An $\mathrm{f} / 2$ medium for marine algae was used as synthetic medium. The composition of the $\mathrm{f} / 2$ medium is described in Table 1 (Guillard and Ryther, 1962; Guillard, 1975). For the preparation of the synthetic medium, sodium nitrate was adjusted to $13.2 \mathrm{mM}$ and the phosphate source was adjusted to $0.7 \mathrm{mM}$. 
Table olive processing water was taken from a local industry located in Arahal, Seville (Spain). TOPW was collected in the months of spring, when the washing process was carried out. TPOW came mainly from washing tanks after $\mathrm{NaOH}$ treatment. For the culture experiments, TOPW was centrifuged to eliminate suspended solids at $4000 \mathrm{rpm}$ for $15 \mathrm{~min}$ and vacuum filtered through a Millipore $0.45 \mu \mathrm{m}$ filter (Albet GF $47 \mathrm{~mm}$, Dassel, Germany). The Physicochemical characterization of table olive processing water and the synthetic medium is shown in Table 2.

\subsection{Experimental procedure}

To prepare the culture medium, TOPW and the components of the synthetic medium, except the vitamins, were sterilized in an autoclave at 121

TABLE 1. Composition of the employed synthetic medium

\begin{tabular}{lcl}
\hline & Concentration & \multicolumn{1}{c}{ Compounds } \\
\hline Nitrogen Source & $1.125 \mathrm{~g} / \mathrm{L}$ & $\mathrm{NaNO}_{3}$ \\
Phosphorus Source & $113 \mathrm{mg} / \mathrm{L}$ & $\mathrm{NaH}_{2} \mathrm{PO}_{4} 2 \mathrm{H}_{2} \mathrm{O}$ \\
Synthetic seawater & $27.12 \mathrm{~g} / \mathrm{L}$ & $\mathrm{NaCl}$ \\
& $5.23 \mathrm{~g} / \mathrm{L}$ & $\mathrm{MgCl}_{2} 6 \mathrm{H}_{2} \mathrm{O}$ \\
& $6.77 \mathrm{~g} / \mathrm{L}$ & $\mathrm{MgSO}_{4} 7 \mathrm{H}_{2} \mathrm{O}$ \\
$1.51 \mathrm{~g} / \mathrm{L}$ & $\mathrm{CaCl}_{2} 2 \mathrm{H}_{2} \mathrm{O}$ \\
& $0.73 \mathrm{~g} / \mathrm{L}$ & $\mathrm{KCl}$ \\
& $0.20 \mathrm{~g} / \mathrm{L}$ & $\mathrm{NaHCO}_{3}$ \\
& $4.36 \mathrm{mg} / \mathrm{L}$ & $\mathrm{EDTA} \mathrm{Na}_{2}$ \\
& $3.15 \mathrm{mg} / \mathrm{L}$ & $\mathrm{FeCl}_{3} 6 \mathrm{H}_{2} \mathrm{O}$ \\
& $10 \mu \mathrm{g} / \mathrm{L}$ & $\mathrm{Cu} \mathrm{SO}_{4} 5 \mathrm{H}_{2} \mathrm{O}$ \\
& $22 \mu \mathrm{g} / \mathrm{L}$ & $\mathrm{Zn} \mathrm{SO}_{4} 7 \mathrm{H}_{2} \mathrm{O}$ \\
& $10 \mu \mathrm{g} / \mathrm{L}$ & $\mathrm{Co} \mathrm{Cl}_{2} 6 \mathrm{H}_{2} \mathrm{O}$ \\
& $180 \mu \mathrm{g} / \mathrm{L}$ & $\mathrm{Mn} \mathrm{Cl}_{2} 4 \mathrm{H}_{2} \mathrm{O}$ \\
& $6 \mu \mathrm{g} / \mathrm{L}$ & $\mathrm{Na}_{2} \mathrm{MoO}_{4} 2 \mathrm{H}_{2} \mathrm{O}$ \\
& $100 \mu \mathrm{g} / \mathrm{L}$ & $\mathrm{Vitamin} \mathrm{B} 1$ \\
& $2 \mu \mathrm{g} / \mathrm{L}$ & $\mathrm{Vitamin} \mathrm{B}_{2}$ \\
& $1 \mu \mathrm{g} / \mathrm{L}$ & $\mathrm{Vitamin}^{\mathrm{H}}$ \\
& &
\end{tabular}

TABLE 2. Physicochemical characterization of table olive processing water and synthetic medium

\begin{tabular}{llcc}
\hline & & TOPW & Synthetic medium \\
\hline pH & & $5.55 \pm 0.04$ & $7.6 \pm 0.3$ \\
Conductivity & $\mathrm{mS} / \mathrm{cm}$ & $17.5 \pm 0.1$ & $50.1 \pm 0.3$ \\
TS & $\mathrm{g} / \mathrm{L}$ & $11.6 \pm 0.1$ & $25.7 \pm 0.2$ \\
VS & $\mathrm{g} / \mathrm{L}$ & $1.9 \pm 0.2$ & $\mathrm{~N} . \mathrm{D}$ \\
VSS & $\mathrm{g} / \mathrm{L}$ & $0.104 \pm 0.001$ & $\mathrm{~N} . \mathrm{D}$ \\
TOC & $\mathrm{mg} / \mathrm{L}$ & $843 \pm 1$ & $\mathrm{~N} . \mathrm{D}$ \\
TN & $\mathrm{mg} / \mathrm{L}$ & $31 \pm 1$ & $123 \pm 1$ \\
Phosphate & $\mathrm{mg} / \mathrm{L}$ & $19.23 \pm 0.06$ & $24.18 \pm 0.22$ \\
Phenols & $\mathrm{mg} / \mathrm{L}$ & $229 \pm 50$ & $\mathrm{~N} . \mathrm{D}$ \\
\hline
\end{tabular}

N.D.; not determined
${ }^{\circ} \mathrm{C}, 1.1$ bars during 15 min (RAYPA Series AES, Barcelona, Spain). Sterilization was carried out in order to minimize interferences in the microalgae biomass growth from microorganisms presented in the resulting media.

Growth experiments were done in 1.0-Lglass bottles in duplicate. The culture media for the growth experiments were different mixtures of synthetic medium and TOPW. The proportion of TOPW in the culture medium was increased at different percentages 10,20, 40 and $80 \%, \mathrm{v} / \mathrm{v}$. Growth experiments were inoculated with the solid fraction that remained after the centrifugation of $100 \mathrm{~mL}$ of stock culture at $4000 \mathrm{rpm}$ for $15 \mathrm{~min}$. Subsequently, growth experiments were carried out in the resulting medium for 15 days, at an aeration rate of $0.5 \mathrm{~L} /(\mathrm{L} \cdot \mathrm{min})$, under solar light of $4.6 \mu \mathrm{mol} /$ $\left(\mathrm{m}^{2} \cdot \mathrm{s}\right)$ and at a temperature of $25 \pm 2{ }^{\circ} \mathrm{C}$.

\subsection{Analytical procedures}

Chemical analyses were used for the characterization of synthetic medium, the TOPW as well as for the effluents from each microalgae culture test at the end of the process. The concentration of volatile solids (VS; g/L), conductivity $(\mathrm{mS} / \mathrm{cm})$ and $\mathrm{pH}$ were carried out according to the recommendations of the Standard Methods of APHA (2005). Additionally, volatile suspended solid concentration (VSS; g/L) was also estimated through the turbidity by measuring the absorbance at $750 \mathrm{~nm}$ (Genesys 10 VIS spectrophotometer, Thermo Scientific, Horshman, England). Additionally, total soluble organic carbon $(\mathrm{TOC} ; \mathrm{mg} / \mathrm{L})$ and total soluble nitrogen $(\mathrm{TN}$, $\mathrm{mg} / \mathrm{L}$ ) were determined from the soluble fraction using a Rosemount analytical Dohrmann DC-190 carbon analyzer. The TOC analyzer was calibrated with a standard solution of potassium phthalate prior to the TOC analyses. Total phenol concentration was quantified by spectrophotometry with the Folin-Ciocalteau method (García et al. 2016).

For microalgae biomass, concentrations of total phenols, proteins, lipids and total carbohydrates were determined. Determinations were carried out after an ultrasound pre-treatment in order to liberate the compounds inside the cell wall and allow a correct quantification. The ultrasound pretreatment was carried out at $200 \mathrm{~W}$ and $24 \mathrm{kHz}$ for $20 \mathrm{~min}$ (UP200S ultrasonic processor, Hielscher, Germany). Samples were placed in an ice-water bath during the pre-treatment to keep the sample at a temperature lower than the boiling point and to avoid significant loss of organic matter. Total phenol concentration was also quantified through the Folin method (García et al. 2016).

The concentration of proteins in the microalgae biomass was measured in accordance to Lowry et al. (1951). $0.1 \mathrm{~mL}$ of sample and $0.3 \mathrm{~mL}$ of distilled water were added to a glass tube. To each tube, $0.4 \mathrm{~mL}$ of 
$\mathrm{NaOH} 1 \mathrm{~N}$ were added. Subsequently, the samples were incubated at $100{ }^{\circ} \mathrm{C}$ in a thermostat dry-block for 10 min (P Selecta multiplaces, Barcelona, Spain), and cooled for $5 \mathrm{~min}$ in a water bath at room temperature. Next, $2 \mathrm{~mL}$ of cupric ion solution and $0.4 \mathrm{~mL}$ of $50 \%(w / v)$ Folin-Ciocalteau reactive were added to each tube. After 30 minutes in the dark, the optical density at $750 \mathrm{~nm}$ was read in a glass cuvette against a reference tube with $0.4 \mathrm{~mL}$ water as sample. The amount of proteins was determined by a standard curve based on the albumin concentration.

Lipid concentration was determined according to Wang et al. (2009). $0.2 \mathrm{~mL}$ of sample was added to a glass tube with a stopper. To each tube, $2 \mathrm{~mL}$ of sulfuric acid $18 \mathrm{M}$ were added. The tubes were incubated at $100{ }^{\circ} \mathrm{C}$ in a thermostat dry-block for 10 $\mathrm{min}$, and cooled for $5 \mathrm{~min}$ in a water bath at room temperature. Next, $5 \mathrm{~mL}$ of phosphoric acid- vanillin reagent was added to each tube and incubated at $37^{\circ} \mathrm{C}$ for $15 \mathrm{~min}$. To prepare the phosphoric acidvanillin reagent, $1.2 \mathrm{~g}$ of vanillin was added to 200 $\mathrm{mL}$ of distillate water, and the volume adjusted to $1 \mathrm{~L}$ with $85 \%$ phosphoric acid. The tubes were then cooled for 10 min in a water bath at room temperature. The optical density at $530 \mathrm{~nm}$ was read in a glass cuvette against a reference tube with $0.2 \mathrm{~mL}$ water as sample. A reference curve was obtained by plotting absorbance against the corresponding lipid concentration ranging from 0.1 to $1.4 \mathrm{~g} / \mathrm{L}$ as determined by the conventional gravimetric method.

A total carbohydrate analysis was made according to the colorimetric method described by Bellou and Aggelis (2013). $0.1 \mathrm{~mL}$ of sample was mixed with $1 \mathrm{~mL}$ of $5 \%(\mathrm{w} / \mathrm{v})$ phenol solution and, subsequently, $2.5 \mathrm{~mL}$ of sulfuric acid (95-98\%) were added. After incubation at room temperature in the dark for $30 \mathrm{~min}$, optical density was determined at $470 \mathrm{~nm}$ using a UV/Vis spectrophotometer (DU 730, Beckman Coulter, USA). The total carbohydrate amount was determined by a standard curve based on glucose concentration.

\subsection{Data fitting}

A First-Order exponential model (FO) was applied to fit the experimental data of the biomass concentration through the turbidity ( $\mathrm{g}$ $\mathrm{VSS} / \mathrm{L}$ ) against the experimental time (eq. 1). The application of the FO model was previously reported for $N$. salina culture by Sforza et al. (2010), and is defined by the equation:

$$
C=C_{0}+C_{\max }[1-\exp (-\mu * t)]
$$

Where $C$ (g VSS/L) is the partial concentration of biomass, $C_{0}$ ( $\mathrm{g}$ VSS/L) is the initial concentration of biomass, $C_{\max }(\mathrm{g} \mathrm{VSS} / \mathrm{L})$ is the maximum concentration of biomass, $\mu\left(\mathrm{d}^{-1}\right)$ is the specific growth rate and $t(\mathrm{~d})$ is the time.

\subsection{Software}

Sigma-Plot software (version 11.0) and Microsoft Excel 2010 were used to create graphs, perform the statistical analysis (mean values and standard deviations) and fit the experimental data to the tendency lines presented in this work.

\section{RESULTS AND DISCUSSION}

\subsection{Microalgae growth in table olive processing water}

The suitability of the TOPW as substrate for growing $N$. gaditana was evaluated through the variations in turbidity and VSS after the 15-day culture period (Figure 1). The initial algal biomass concentration was similar for the different growth experiments, with a mean value of turbidity of $0.72 \pm 0.20 \mathrm{~g} \mathrm{VSS} / \mathrm{L}$. According to Figure 1, N. gaditana has grow in a medium enriched with TOPW at percentages from 10 up to $40 \%$, with a mean value of increase of 0.32 $\pm 0.03 \mathrm{~g} \mathrm{VSS} / \mathrm{L}$. Within this range, the highest increment of turbidity was determined at a percentage of $40 \%$ of TOPW, reaching an increment of up to $0.36 \pm$ $0.05 \mathrm{~g} \mathrm{VSS} / \mathrm{L}$; i.e. an algal biomass concentration of $0.44 \pm 0.06 \mathrm{~g} \mathrm{VSS} / \mathrm{L}$ at the end of the culture period. $80 \%$ of TOPW in the culture mixture entailed a poor growth of algal biomass, reaching a value of turbidity of $0.19 \pm 0.30 \mathrm{~g} \mathrm{VSS} / \mathrm{L}$, around $43 \%$ lower than the value described for $40 \%$ of TOPW (Figure 1). A maximum algal biomass concentration of $0.72 \mathrm{~g}$ VSS/L was recently reported for $N$. Salina in $22 \mathrm{~g}$ sterilized sea salts per L solution enriched with $\mathrm{f} / 2$ Guillard (Sforza et al., 2012). The reduction of this difference and an improvement in the algal biomass concentration could be reached by the employment of microalgae adapted to the specific conditions of TOPW or by promoting the formation of consortiums with other microalgae or bacteria species. An adaptation process could also entail an increment in

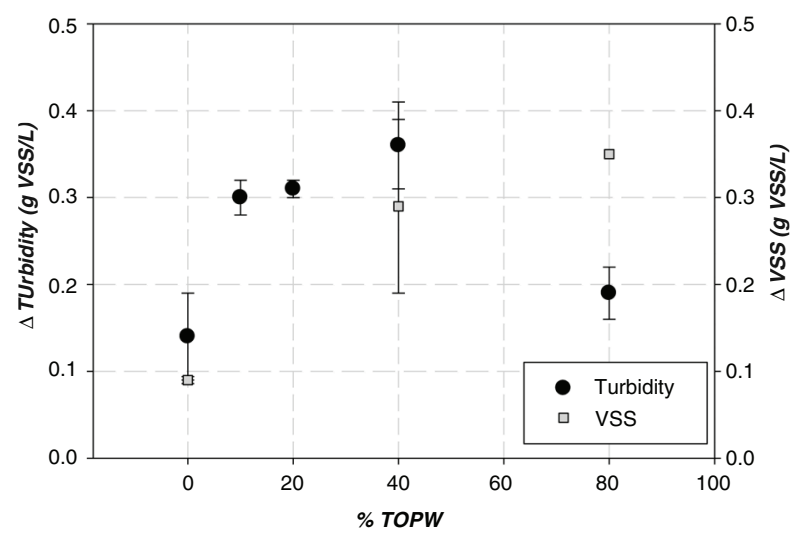

FIGURE 1. Variation of turbidity (g VSS/L) and VSS (g VSS/L) after a 15-day growth period for the different percentages of TOPW $(\%)$. 
the TOPW percentage that could be treated without affecting the microalgae biomass growth.

The values of VSS presented similar values and trends to the turbidity values in the experiments with TOPW percentages up to $40 \%$ (Figure 1), although a high difference at $80 \%$ TOPW was found. This difference could be explained by a marked growth of bacteria in relation to the growth of $N$. gaditana at $80 \%$ TOPW.

\subsection{Microalgae composition and recovery potential}

The valorization of the obtained microalgae biomass depends on the concentration of proteins, total carbohydrates and lipids, which are determined from the most recommended valorization process. These principal compound groups were quantified in the microalgae biomass at the end of each growth experiment. Figure 2 shows the content of proteins, total carbohydrates and lipids per gram of VSS at the different percentages of TOPW used. Proteins were the major compounds; they represented between $56-74 \%$ of the total content, with much higher percentage than those obtained for lipids and total carbohydrates (Figure 2). In the growth experiments at $20 \%$ of TOPW, the highest content of proteins was reached, i.e. $0.73 \mathrm{~g}$ of proteins/g VSS. Interestingly, the production of proteins per litre of growth culture was very similar for the experiments at between $10 \%$ and $40 \%$ of TOPW with a mean value of $0.19 \pm$ $0.03 \mathrm{~g}$ of proteins/L. The productions at $0 \%$ and $80 \%$ of TOPW were $0.07 \pm 0.01 \mathrm{~g}$ of proteins/L, around $64 \%$ lower than those achieved in the above range of TOPW percentages. Lipid and total carbohydrate concentrations were very similar at the different TOPW proportions with mean values of $0.15 \pm 0.04$ $\mathrm{g} / \mathrm{g}$ VSS and $0.14 \pm 0.06 \mathrm{~g} / \mathrm{g}$ VSS, respectively.

Phenols are other valuable compounds present in the TOPW whose retention by the microalgae biomass could help its valorization. Figure 3 shows the total

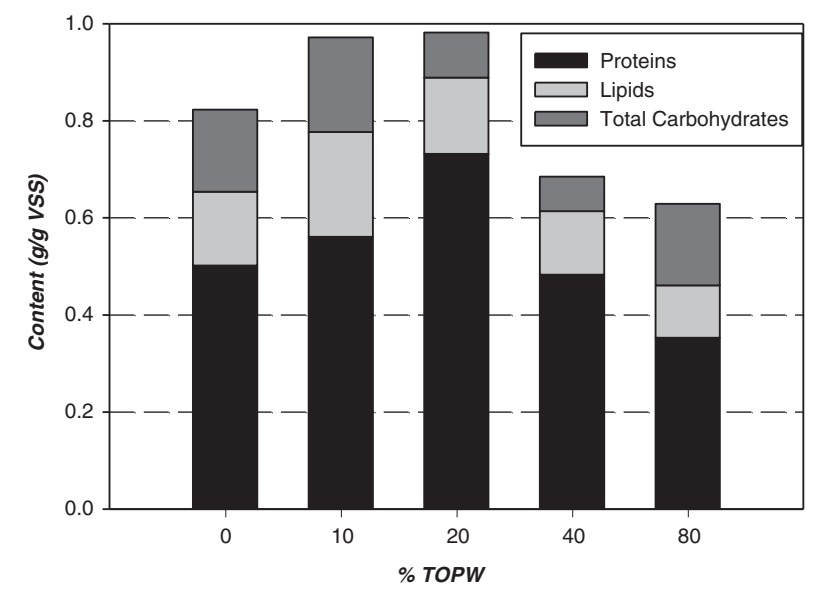

FIGURE 2. Content of proteins, lipids and total carbohydrates (g/gVSS) at the end of the growth period for the different percentages of TOPW $(\%)$. phenol content per gram of microalgal VSS at the different percentages of TOPW in the growth experiments. Total phenol contents in microalgal biomass reached very similar concentrations for the experiments at $10-40 \%$ of TOPW with a mean value of $0.020 \pm$ $0.002 \mathrm{~g}$ of total phenols/g VSS (Figure 3). Increasing the TOPW percentage in the growth experiment up to $80 \%$ entailed a marked decrease in the retention of the total phenols by the microalgae biomass, reaching a value of $0.009 \pm 0.001 \mathrm{~g}$ of total phenols $/ \mathrm{g}$ VSS, around 54\% lower. Therefore, in the studied conditions, $40 \%$ of TOPW could be considered as the most interesting percentage of mixture to be treated given that it allows for the treatment of the highest percentage of TOPW without decreasing the concentrations of valuable compounds and microalgae biomass.

\subsection{Microalgae as water treatment for nutrient removal}

The use of TOPW to grow microalgae biomass also implies the decrease of nutrient concentrations in the TOPW, which can be seen as a process water treatment. Table 3 shows the concentration of $\mathrm{TN}$, phosphate, TOC and total phenols in the growth medium at the beginning and the end of the 15-day experimental time. As can be seen, the concentration at day 0 of TN, TOC and total phenols in the growth medium strongly depended on the TOPW percentage, which presented a low concentration of TN but contributed to the TOC and total phenols. The TN removal efficiency determined at $80 \%$ of TOPW was significantly higher than those obtained for the other TOPW percentages, reaching $74 \%$ of $\mathrm{TN}$ removal. Regardless of the initial TN concentration, the quantity of TN fixed by the microalgae biomass per $\mathrm{L}$ of growth culture was similar in all the growth experiments, i.e. around $32 \pm 10 \mathrm{mg} \mathrm{N} / \mathrm{L}$. TOC removal efficiencies at $20-80 \%$ of TOPW were

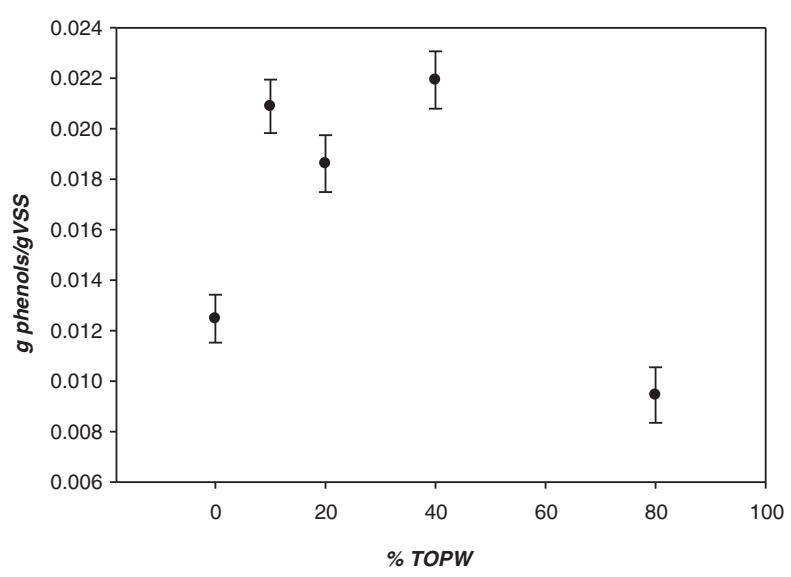

FIGURE 3. Content of total phenols (g phenols/g VSS) retained in the microalgae biomass for the different percentages of TOPW $(\%)$. 
6 - C.G. Contreras, A. Serrano, G. Ruiz-Filippi, R. Borja and F.G. Fermoso

TABLE 3. Initial and final TN, phosphate, TOC and total phenol concentrations in the growth medium at different percentages of TOPW

\begin{tabular}{lccccc}
\hline & Day & \% TOPW 10 & $\mathbf{2 0}$ & $\mathbf{4 0}$ & $\mathbf{8 0}$ \\
\hline TN (mg/L) & 0 & $167 \pm 1$ & $137 \pm 28$ & $110 \pm 24$ & $61 \pm 2$ \\
Phosphate (mg/L) & 15 & $140 \pm 1$ & $101 \pm 29$ & $89 \pm 4$ & $16 \pm 4$ \\
& 0 & $23 \pm 1$ & $22 \pm 1$ & $19 \pm 1$ & $14 \pm 1$ \\
TOC (mg/L) & 15 & $18 \pm 1$ & $12 \pm 1$ & $9 \pm 1$ & $10 \pm 1$ \\
& 0 & $144 \pm 12$ & $204 \pm 4$ & $367 \pm 5$ & $735 \pm 50$ \\
Total phenols (mg/L) & 15 & $84 \pm 3$ & $53 \pm 3$ & $125 \pm 1$ & $273 \pm 62$ \\
& 0 & $20 \pm 1$ & $41 \pm 2$ & $85 \pm 3$ & $156 \pm 3$ \\
\hline
\end{tabular}

similar, with a mean value of $68 \pm 4 \%$. This value was $63 \%$ higher compared to removal efficiency determined at $10 \%$ of TOPW (Table 3). Total phenols were effectively removed from the growth medium, even at the highest initial concentration, i.e. $80 \%$ of TOPW, which reached a removal efficiency of up to $71 \%$. The phosphate removal efficiencies ranged from $22 \%$ to $53 \%$, with the highest value determined at $40 \%$ of TOPW (Table 3).

The use of TOPW to grow microalgae biomass presents an interesting option for removing nitrogen, phosphorus, phenols and organic matter from a processing water which is very difficult to be biodegraded, given its high content in toxic compounds. Although high removal efficiencies of nutrients were determined, microalgae biomass culture should be enhanced if it is to become a suitable integral processing water treatment.

\subsection{Time required to maximize the valorization process}

According to previously described results, $40 \%$ of TOPW could be considered as the most interesting dilution percentage in the studied conditions. In order to determine the time required to maximize the valorization process, microalgae biomass concentration and composition were monitored versus time throughout the growth experiment at $40 \%$ TOPW. Figure 4 shows the turbidity values (g VSS/L) against the culture period (d). The microalgae biomass increased from $0.09 \pm 0.01 \mathrm{~g} \mathrm{VSS} / \mathrm{L}$ up to a mean value of $0.42 \pm 0.02 \mathrm{~g} \mathrm{VSS} / \mathrm{L}$ at the end of the growth experiments. Although the maximum microalgae biomass concentration was reached after a 13 -day period, $51 \%$ and $75 \%$ of this increase were reached after the 3-day and 8-day periods, respectively. Figure 4 also shows the results of applying a FO model to the experimental data, which presented a good fitting with a value of $r^{2}$ of 0.964 . The FO model also correctly predicted $C_{\max }$, with a difference between the experimental and the modeled values of lower than 5\%. The FO model also includes the specific growth rate, which allows for the evaluation of the kinetics of the process. At the proposed experimental conditions, specific growth rate was found to be $0.16 \pm 0.04 \mathrm{~d}^{-1}$. This value was lower than that obtained by Sforza et al. (2012) in cultures of $N$. Salina $\left(0.49 \mathrm{~d}^{-1}\right)$ in sterilized sea salt solutions enriched with a f/2 Guillard solution. The marked difference underlines the process and should be optimized by, for example, adapting microalgae and bacteria consortium to TOPW characteristics.

Microalgae biomass composition remains slightly constant after 6 days with mean values of $0.74 \pm 0.04 \mathrm{~g} / \mathrm{g}$ VSS of proteins, $0.12 \pm 0.01 \mathrm{~g} / \mathrm{g}$ VSS of lipids, $0.02 \pm 0.01 \mathrm{~g} / \mathrm{g}$ VSS of total carbohydrates and $0.03 \pm 0.01 \mathrm{~g} / \mathrm{g}$ VSS of total phenols (Figure 5). Proteins were the main compound group, reaching a concentration of $271 \mathrm{mg}$ of proteins/L of growth medium after an 8-day period. An increase in the growth period entailed a low increase in the protein concentration, which reached a maximum concentration of up to $317 \mathrm{mg}$ of proteins/L of growth medium after a 16-day period; i.e. an increase of $17 \%$ by doubling the growth period. Lipids were

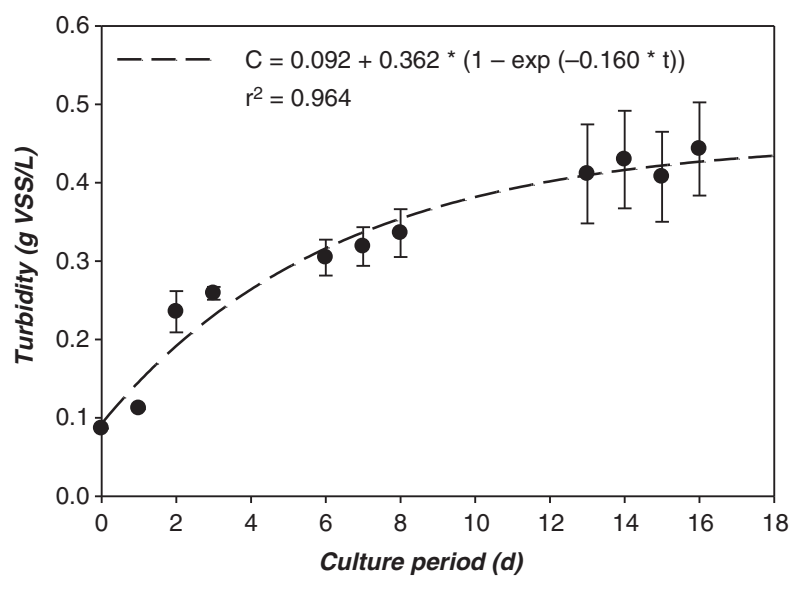

FIGURE 4. Variation of turbidity (g VSS/L) versus time throughout the culture period for experiments at $40 \%$ of TOPW. 


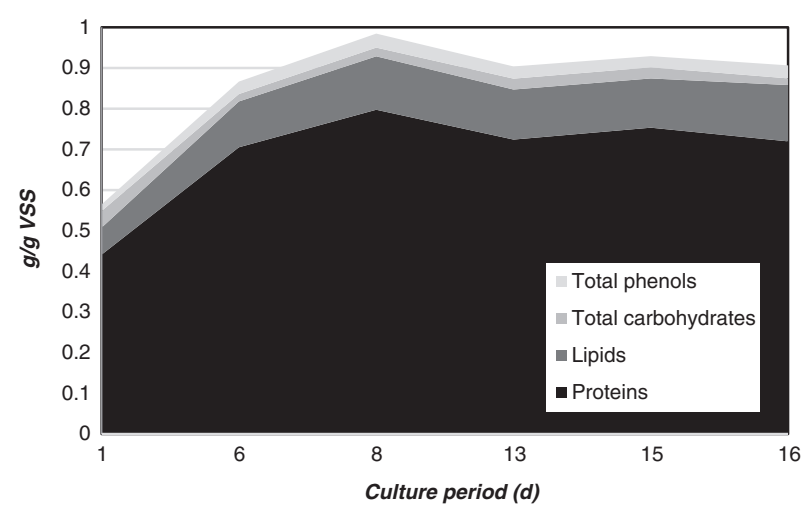

FIGURE 5. Variation of the concentration of total phenols, total carbohydrates, lipids and proteins (g/g VSS) versus time throughout the culture period for experiments at $40 \%$ of TOPW.

also accumulated in the microalgae biomass by increasing the growth period, reaching a maximum concentration of $44 \mathrm{mg}$ of lipids/L of growth medium after an 8-day period. Total carbohydrates and total phenols remained practically constant throughout the growth period.

\section{CONCLUSIONS}

- $\quad$.gaditana using TOPW was effectively grown up to a proportion of $40 \%$ TOPW.

- Proteins were the major compounds in the grown microalgae biomass (56-74\%).

- Phenols were retained in the microalgae biomass up to a mean concentration of $0.020 \pm$ $0.002 \mathrm{~g}$ of total phenols/g VSS.

- Efficiency of phenol removal was very high, reaching a value up to $81 \%$ in $40 \%$ TOPW experiments.

- Experiments of $80 \%$ TOPW resulted in a low production of biomass and valuable products.

\section{ACKNOWLEDGEMENTS}

The authors are grateful to the Marie Curie International Research Staff Exchange Scheme (IRSES) "Renewable energy production through microalgae cultivation: closing material cycles" (PIRSES-GA-2011-295165) for funding this research. The authors would also like to thank the Spanish Ministry of Economy and Competitiveness for providing financial support through Project CTM2014-55095-R.

\section{REFERENCES}

American Public Health Association (APHA), American Water Works Association (AWWA) \& Water Environment Federation (WEF). 2005. Standard Methods for the Examination of Water and Wastewater, 21st Edition. Washington DC, USA.
Ayed L, Asses N, Chammem N, Hamdi M. 2015. Improvement of green table olive processing wastewater decolorization by Geotrichum candidum. Desalin. Water Treat. 1-11.

Bellou S, Aggelis G. 2013. Biochemical activities in Chlorella sp. and Nannochloropsis salina during lipid and sugar synthesis in a lab-scale open pond simulating reactor. J. Biotechnol. 164, 318-329.http://dx.doi.org/10.1016/j. jbiotec.2013.01.010

Brenes M, De Vicent J, García P, Garrido A. 1989. Characteristics of the waste waters from the elaboration of table olives. Grasas Aceites, 40, 287-290.

García A, Rodríguez-Juan E, Rodríguez-Gutiérrez G, Rios JJ, Fernández-Bolaños J, 2016. Extraction of phenolic compounds from virgin olive oil by deep eutectic solvents (DESs). Food Chem. 197, 554-561.http://dx.doi. org/10.1016/j.foodchem.2015.10.131

Gerde JA, Wang T, Yao L, Jung S, Johnson LA, Lamsal B. 2013. Optimizing protein isolation from defatted and nondefatted Nannochloropsis microalgae biomass. Algal Res. 2 , 145-153. http://dx.doi.org/10.1016/j.algal.2013.02.001

Guillard RR, Ryther JH. 1962. Studies of marine planktonic diatoms. I. Cyclotella nana Hustedt, and Detonula confervacea (cleve) Gran. Can. J. Microbiol. 8, 229-239.http:// dx.doi.org/10.1139/m62-029

Guillard RRL. 1975. Culture of Phytoplankton for Feeding Marine Invertebrates, in Smith WL, Chanley MH (Eds.) Culture of Marine Invertebrate Animals: Proceedings 1st Conference on Culture of Marine Invertebrate Animals Greenport. Boston, MA: Springer US.

IOOC, International Olive Oil Council, 2011. World Table Olive Figures. http://www.internationaloliveoil.org/estaticos/view/ 132-world-table-olive-figures. URL seen on 29th February 2016.

Kaçka A, Donmez G. 2008. Isolation of Dunaliella sp. from a hypersaline lake and their ability to accumulate glycerol. Bioresource Technol. 99, 8348-8352. http://dx.doi. org/10.1016/j.biortech.2008.02.042

Lowry OH, Rosebrough NJ, Farr AL, Randall RJ. 1951. Protein measurement with the Folin phenol reagent. J. Biol.Chem. 193, 265-275.

Millao S, Uquiche E. 2016. Antioxidant activity of supercritical extracts from Nannochloropsis gaditana: correlation with its content of carotenoids and tocopherols. J. Supercrit. Fluid. 111, 143-150. http://dx.doi.org/10.1016/j. supflu.2016.02.002

Montingelli ME, Tedesco S, Glabi AG. 2015. Biogas production from algal biomass: A review. Renew. Sust. Energ. Rev. 43, 961-972. http://dx.doi.org/10.1016/j. rser.2014.11.052

Parinos CS, Stalikas CD, Giannopoulos ThS, Pilidis GA. 2007. Chemical and physicochemical profile of wastewaters produced from the different stages of Spanish-style green olives processing. J. Hazard. Mater. 145, 339-343. http:// dx.doi.org/10.1016/j.jhazmat.2006.12.061

Sanchez AH, García P, Rejano PL. 2006. Trends in table olive production. Elaboration of table olives. Grasas Aceites 57, 86-94.

Sforza E, Bertucco A, Morosinotto T, Giacometti GM. 2010. Vegetal oil from microalgae: Species selection and optimization of growth parameters. Chem. Eng. Trans. 20, 199-204.

Sforza E, Bertucco A, Morosinotto GM. 2012. Photobioreactors for microalgae growth and oil production with Nannochloropsis salina: From lab.-scale experiments to large-scale design. Chem. Eng. Res. Des. 90, 9, 1151-1158. http://dx.doi.org/10.1016/j.cherd.2011.12.002

Wang J, Li R, Lu D, Ma S, Yan Y, Li W. 2009. A quick isolation method for mutants with high lipid yield in oleaginous yeast. World J. Microbiol. Biotechnol. 25, 921-925. http:// dx.doi.org/10.1007/s11274-009-9960-2

Wang L, Min M, Li Y, Chen P, Chen Y. 2010. Cultivation of green algae Chlorella sp. in different wastewaters from municipal wastewater treatment plant. Appl. Biochem. Biotech. 162, 1174-1186. http://dx.doi.org/10.1007/s12010009-8866-7 